\title{
Sorbin and SH3 Domain-Containing Protein 2
}

National Cancer Institute

\section{Source}

National Cancer Institute. Sorbin and SH3 Domain-Containing Protein 2. NCI Thesaurus.

Code C126604.

Sorbin and SH3 domain-containing protein 2 (1100 aa, 124 kDa) is encoded by the human SORBS2 gene. This protein plays a role in linking signaling proteins to the cytoskeleton. 